\title{
)Degree of search of acupuncture as a therapeutic option in a population sample of Lisbon
}

\section{Grau de procura da acupunctura como opção terapêtica numa amostra da população de Lisboa}

\author{
Maria do Céu Costa ${ }^{1,2,3}$, Catarina Gonçalves ${ }^{3}$, Cláudia Oliveira ${ }^{3} \&$ Helena Pinto Ferreira $^{4}$
}

'CBIOS - Research Center for Health Science and Technologies, Universidade Lusófona \& ERISA -Escola Superior de Saúde Ribeiro

Sanches, Campo Grande, 376, 1749-024, Lisboa, Portugal

${ }^{2}$ LNEG, Estrada da Portela, Bairro do Zambujal - Alfragide, Apartado 7586, Alfragide, 2610-999 - AMADORA

${ }^{3}$ SPFito- Sociedade Portuguesa de Fitoquímica e Fitoterapia, Rua da Sociedade Farmacêutica, 18

1169-075 Lisboa

${ }^{4}$ SPMA- Sociedade Portuguesa Médica de Acupunctura, Secção Regional do Centro da Ordem dos Médicos, Avenida Afonso

Henriques, 39

3000-011 Coimbra

Email: p1658@ulusofona.pt; ceu.costa@lneg.pt

\begin{abstract}
This is an exploratory and correlational study, with an initial number of 150 participants using a convenience sampling from five medical clinics and five centers of traditional Chinese medicine in Lisbon, where subjects were allowed to respond voluntarily to questionnaires. A response rate of $74 \%(\mathrm{~N}=111)$ was achieved. Adherence to acupuncture is higher in females and in the age group 31-50 years (40\% men and 48\% women). Muscle and joint problems, in addition to psychological disorders are described as the most common reasons for recourse to acupuncture, although it is also referred to as an effective treatment for other types of complaints. However, acupuncture is not the first treatment that the people turn to. It is recognized that results may occur in the medium to long term and after several therapy sessions. This does not seem to affect the study population's perception of the treatment which is shown to be content with very good and/or good value for money (53\%). Overall, the majority of the population (93\%) relies on the therapy for the good and/or very good (79\%) or reasonable (16\%) results obtained, and shows trust (88\%) in the competences of the health care provider who performs the acupuncture.
\end{abstract}

Keywords: Acupuncture; Trust; Satisfaction; Main Complaint, Sex and Age Group.

\section{Resumo}

Este é um estudo exploratório e correlacional, com um número inicial de 150 participantes, utilizando uma amostra de conveniência constituída por cinco clínicas médicas e cinco casas de medicina tradicional chinesa, em Lisboa, onde os indivíduos foram autorizados a responder voluntariamente a questionários. Apresenta uma taxa de resposta de $74 \%(\mathrm{~N}=111)$. A adesão à acupunctura é maior no sexo feminino e na faixa etária de 31 a 50 anos ( $40 \%$ homens e $48 \%$ mulheres). A procura de tratamento de problemas musculares e articulares e para problemas do foro psicológico são as mais descritas, apesar de ser referida como eficaz noutro tipo de queixas, e não ser o primeiro tipo de tratamento que a população procura. É reconhecido que os resultados podem ocorrer a médio e longo prazo, após várias sessões terapêuticas, o que não parece afetar a perceção da população em estudo que se diz satisfeita (53\%) com uma muita boa e / ou boa relação benefício-custo. Em geral, a maioria da população (93\%) confia na terapia pelo resultado bom ou muito bom (79\%) ou razoável (16\%) obtido, e deposita confiança $(88 \%)$ nas competências do profissional de saúde que executa a acupunctura.

Palavras-chave: Acupunctura; Confiança; Satisfação; Principais Queixas; Sexo e Faixa Etária. 


\section{Introduction}

The term "acupuncture" is derived from the Latin words acus, which means needle, and puncture, which means prick. This is a potentially valuable technique for treating a wide range of situations. It involves the insertion of needles at specific points on the skin to stimulate or balance the flow of vital energy ${ }^{(1)}$ according to the more traditional school, or as a neuromodulation technique via insertion of metallic needles along the path of nerves and neurovascular bundles. There are now numerous studies on the efficacy of acupuncture in the treatment of many health problems such as asthma, pain triggered by kidney stones, muscle problems, constipation, arthritis, spinal pain, trigeminal neuralgia and pain after surgery.

A large scale study in the United States in 2002 involving more than thirty thousand adults was undertaken to find out, specifically, to what extent patients of neurosurgery adhered to Complementary and Alternative Medicine (Complementary and Alternative Medicine (CAM)) and the level of knowledge of neurosurgeons regarding CAM therapies (acupuncture, plants, massage, spirituality, yoga). The results of the study revealed that $\geqslant 75 \%$ of the adults surveyed admitted practice or discussion of these therapies. Among neurosurgeons, 50\% revealed that they discuss the benefits of acupuncture among colleagues. The findings highlighted that about $36 \%$ of American adults use complementary and alternative medicine as a treatment in many situations ${ }^{(2)}$.

However, in Portugal, there are no papers on this subject that contain statistics about the behavior in these areas, in particular in relation to acupuncture which is recognized as a specialty by the Medical Association. In fact, in Portugal, in May 2002 the Medical Competence in Medical Acupuncture was approved by the National Medical Council Executive Committee which regulates the practice of this treatment technique.

Almeida ${ }^{(3)}$ recently discussed the case of acupuncture and homeopathy in Portugal and considered the differential incorporation of CAM into the medical establishment. The paper argues that the differential responses of the Portuguese medical establishment to acupuncture and homeopathy are due to reasons beyond those given involving medical rhetoric of insufficient scientific evidence for homeopathy, and which extend to issues of the medical prejudice or 'resistance to innovation' of the Portuguese Medical Council, as well as issues of professional status or power.

A survey ${ }^{(4)}$ exploring practice characteristics and research priorities of practitioners of traditional acupuncture in China and the EU (1126 survey responses, 1020: $559 \mathrm{EU}$, including 2 from Portugal, 461 China) identified differences in practice and training between acupuncturists in China and the EU and between EU member states. It proposes that the

\section{Introdução}

IO termo «acupunctura» deriva das palavras latinas acus, que significa agulha e punctura que significa picada. É um tratamento potencialmente valioso para uma vasta gama de situações, que envolve a inserção de agulhas em pontos específicos da pele para estimular ou equilibrar o fluxo de energia vital ${ }^{(1)}$, segundo a escola mais tradicional, ou como uma técnica de neuromodulação, através da inserção de agulhas metálicas ao longo do trajeto de nervos e feixes neurovasculares.

Existem já numerosos estudos da eficácia da acupunctura no tratamento de diversos problemas de saúde, como asma, dor desencadeada por cálculos renais, problemas musculares, obstipação, artrite, dores na coluna vertebral, neuralgia do trigémeo e dor após uma cirurgia.

Um inquérito realizado em grande escala, a mais de trinta mil adultos, em 2002, nos Estados Unidos, para saber, em concreto, qual a adesão às Medicina Complementar e Alternativa (Complementary and Alternative Medicine (CAM)) dos doentes de neurocirurgia, e o conhecimento dos neurocirurgiões sobre as terapias CAM (acupunctura, plantas, massagens, espiritualidades, ioga), teve como resultado a revelação de que a sua prática ou discussão é admitida por $\geqslant 75 \%$ dos adultos inquiridos. Entre os neurocirugiões, $50 \%$ revelaram discutir os benefícios da acupunctura entre colegas. Entre as conclusões constatou-se que cerca de $36 \%$ dos adultos americanos utilizam a medicina alternativa e complementar como tratamento em diversas situações ${ }^{(2)}$.

Porém, em Portugal, não foram encontrados artigos científicos sobre este assunto contendo dados estatísticos acerca do comportamento nestas áreas, em particular relativamente à acupunctura que é reconhecida como especialidade pela Ordem dos Médicos. De facto, em Portugal, em Maio de 2002 foi aprovada pelo Conselho Nacional Executivo da Ordem dos Médicos a Competência Médica em Acupunctura, que regula a prática desta técnica terapêutica.

A socióloga Almeida ${ }^{(3)}$ discutiu recentemente o caso da acupuntura e homeopatia em Portugal, considerando a incorporação diferencial de CAM para o estabelecimento do ato médico. $\mathrm{O}$ documento argumenta que as respostas diferenciais da prática médico Português de acupuntura e homeopatia são devidas a razões para além da retórica médica de evidência científica insuficiente para a homeopatia, e que se estende a questões de preconceito médico ou 'resistência à inovação" da Ordem dos Médicos Portuguesa e ao estatuto profissional ou de poder.

Um estudo exploratório ${ }^{(4)}$ de características práticas e prioridades de praticantes de acupuntura tradicional na China e na União Europeia (1126 respostas da pesquisa, 1020: 559 UE, China 461) identificou diferenças na prática e formação entre acupunctores na China e na UE 
creation of collaborative networks is crucial in overcoming these differences and to facilitate international, multi-centre clinical trials.

The only known study with a sample of the Portuguese population was published 12 years ago by the Consumer Protection-DECO ${ }^{(5)}$ which carried out a survey through questionnaires, to find out the satisfaction level of respondents in relation to the results obtained from acupuncture.

This study was conducted in order to understand whether or not acupuncture is a preference for the treatment of certain types of problem and to distinguish what these problems are. In a random population sample, we aimed to ascertain the respondents' motivation for using this type of therapy and the results they reported. At the same time, we intended to ascertain opinions about the degree of trust and satisfaction with the therapy, from a simple random sample of the users of a cluster of 10 acupuncture practitioners in Lisbon.

\section{Methodology}

It was believed to be relevant to investigate if and how acupuncture is considered as an option in the treatment of certain diseases. We used a study of an exploratory nature and surveyed the population attending 10 clinics/centers selected by convenience of location in the Lisbon region. The issues listed below have served as a guideline for this research:

1. Do women seek this type of therapy more than men?

2. Is the search for Acupuncture higher in centers of traditional Chinese medicine than in western medical clinics?

3. In general, do people rely more on the realization of this therapy in physicians' clinics than in centers of traditional Chinese medicine?

4. Do people turn to these clinics/centers of their own choice?

5. Do people from older age groups adhere to this therapy more than people of younger age groups?

6 . Do people with anxiety problems seek acupuncture therapy more than people with localized pain?

7. Are people who undergo this type of therapy satisfied with the results?

In order to find answers to the research questions listed above, we used a non-experimental method with the distribution of 15 anonymous questionnaires per clinic/center. The clinics/centers for this study (10) were selected at random, that is, from information collected orally by the authors of this study in answer to the question: "Do you know any clinic/center where acupuncture is practiced in the Lisbon area?". The intention was to get an equal number of both centres for traditional Chinese medicine ${ }^{(5)}$ and western medical clinics ${ }^{(5)}$.

The questionnaire was designed for this purpose and e entre estados membros da UE, e propõe a criação de redes de colaboração para superar essas diferenças e facilitar ensaios clínicos internacionais, multicêntricos. $\mathrm{O}$ único estudo conhecido com uma amostra de população portuguesa foi publicado há 12 anos pela Direção-Geral de Defesa do Consumidor-DECO ${ }^{(5)}$, realizado através de questionários, para conhecer a satisfação dos inquiridos relativamente aos resultados obtidos com a adesão à acupunctura.

O presente estudo foi conduzido com o objetivo de perceber se a acupunctura é ou não uma preferência para o tratamento de determinado tipo de problemas, e quais, e conhecer os motivos e resultados descritos por uma amostra aleatória da população enquanto recorre a esta terapia; simultaneamente, pretendeu-se conhecer a opinião sobre o grau de confiança e satisfação com a terapia, num grupo constituído pela amostra aleatória simples dos utentes de 10 espaços de prática de acupunctura, em Lisboa.

\section{Metodologia}

Considerando pertinente saber se e porquê a acupunctura é tida em conta como opção de escolha, no tratamento de determinadas patologias, recorreu-se a um estudo de caráter exploratório, em que se estudou a população da região de Lisboa que frequenta 10 clínicas selecionadas por conveniência de localização. As questões abaixo mencionadas serviram de fio condutor para esta investigação:

1. As mulheres procuram mais este tipo de terapia que os homens?

2. A procura pela acupunctura é superior nas casas de medicina tradicional chinesa?

3. Em geral, as pessoas confiam mais na realização desta terapia em consultórios médicos do que em casas de medicina tradicional chinesa?

4. As pessoas recorrem a estes locais por opção própria?

5. Pessoas com uma faixa etária mais elevada aderem mais a esta terapia que pessoas de faixas etárias mais baixas?

6. Pessoas com problemas de ansiedade recorrem mais à terapia do que pessoas com dores localizadas?

7. As pessoas que fazem este tipo de terapêutica estão satisfeitas com os resultados obtidos?

Com o objetivo de encontrar resposta às perguntas de investigação, recorreu-se a um método não experimental, com distribuição de 15 questionários anónimos, por clínica. As clínicas para este estudo (10) foram selecionadas de modo aleatório, isto é, por informação recolhida oralmente em resposta à pergunta: "Conhece alguma Clínica onde se pratique acupunctura na região de Lisboa?" às orientadoras deste estudo. Pretendeu-se número igual (5) de casas de medicina tradicional chinesa e (5) consultórios médicos de medicina ocidental, dita convencional. 
distributed to all 10 addresses, which were obtained after meeting with the directors and explaining the objectives of the study. It was agreed that the acupuncture clients' responses would be collected in an envelope in the period from December 2010 to April 2011. In the questionnaire, one open question asked about why they were undergoing acupuncture by inviting the respondent to choose up to five of the possible options and to put them in a order of preference. The questionnaire started with a brief identification of the user, so that it would be possible to identify sex and age group, followed by issues related to the reason that led the patient to choose this therapy and whether or not it had been recommended, and if so, by whom. The patient was also questioned about the duration of treatment, the location and the practitioner. The questionnaire ended with questions about the level of trust and satisfaction with the treatment, through the perception of value for money based on a benefit-cost ratio, and competence demonstrated by the acupuncturist. The data obtained from the questionnaires were processed by using Microsoft Office Excel.

\section{Results}

Of the 150 questionnaires distributed, 111 (74\%) were completed by respondents participating in the study. Among the respondents, 81 were female and 30 were male (Figure 1). The distribution of the subjects of both sexes being treated with acupuncture was similar in each age group, although the percentage was slightly higher in women $(8 \%)$ aged between 31 and 50 years and higher in children and adolescent males up to 18 years (7\%), as pictured in Figure 2.

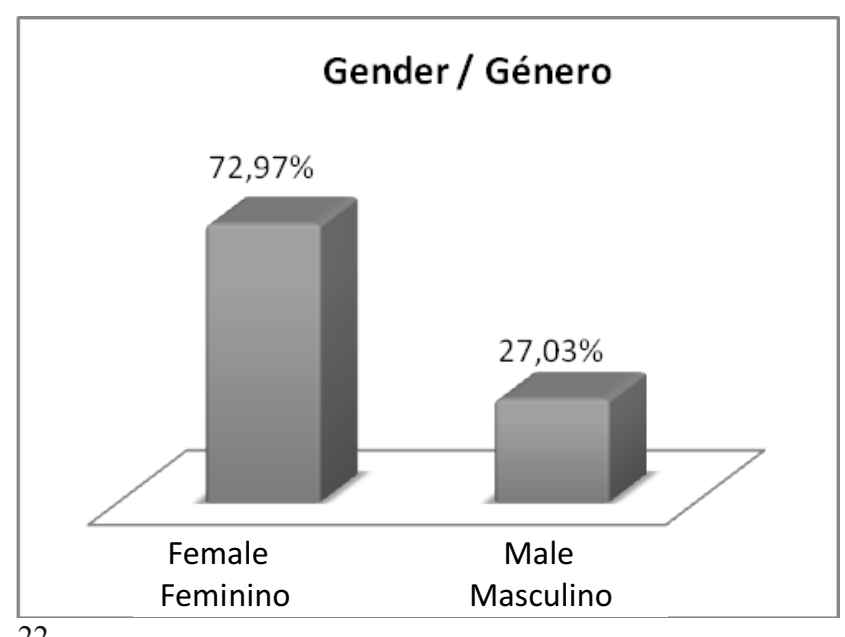

O questionário foi elaborado para o efeito e distribuído por todas as 10 moradas obtidas, após reunião com o Diretor, explicando os objetivos do estudo e acordo do/a responsável para recolha das respostas dos utentes de acupunctura em envelope, no período de Dezembro de 2010 a Abril de 2011. A formulação de uma única questão aberta sobre problemas pelos quais frequentava a acupunctura convidava a enumerar até 5 dos principais, colocando-os por ordem, estando as possíveis respostas previamente fixadas. Iniciando com uma breve identificação do utente, de forma a ser possível identificar sexo e faixa etária, seguiram-se questões relacionadas com a razão que levou o doente a escolher esta terapia e se foi ou não recomendada; se sim, por quem, foi recomendada. $O$ doente foi também interrogado acerca do período de tempo do tratamento, o local e sobre quem o executa. $\mathrm{O}$ questionário finalizou com questões sobre o grau de confiança e satisfação em relação ao tratamento, através da relação benefício-custo estimada pela perceção da qualidade do efeito em função do preço e da competência demonstrada pelo seu acupunctor. Os dados obtidos nos questionários foram tratados através do programa Microsoft Office Excel.

\section{Resultados}

Dos 150 questionários entregues, foram respondidos por 1111inquiridos que fazem acupunctura nas clínicas aderentes ao estudo, o que corresponde a uma taxa de adesão de $74 \%$. Entre as 111 pessoas que participaram no estudo, 81 pertencem ao sexo feminino e apenas 30 ao sexo masculino (Figura 1), sendo geralmente semelhante a adesão em cada sexo, em cada grupo etário, embora ligeiramente maior nas mulheres $(8 \%)$, apenas entre os 31 a 50 anos (Figura 2), e maior nas crianças e adolescentes do sexo masculino até aos 18 anos (7\%).

Figure 1 - Characterization of test sample

Figura 1 - Caracterização da amostra em estudo. 


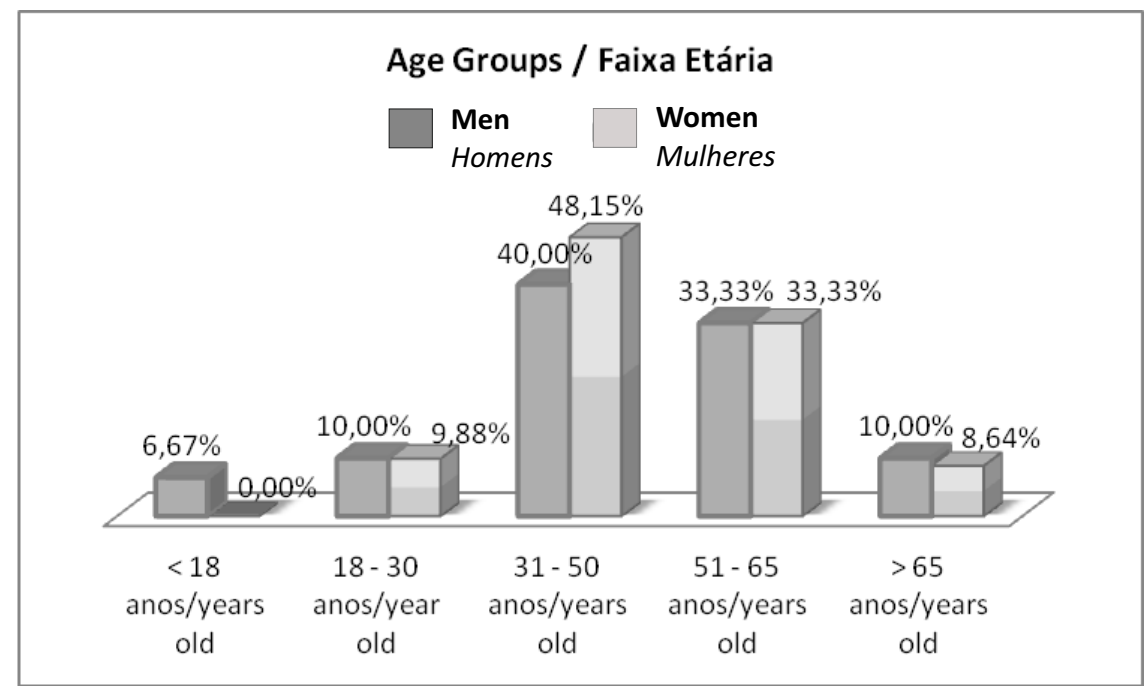

Figure 2 - Distribution of participants in proportion, according to sex and age.

Figura 2 - Distribuição dos participantes, em percentagem, segundo o sexo e idade.

The gender distribution of participants was homogeneous in two groups: those $53 \%$ of men / women who had previously been treated with acupuncture to treat the same or another kind of problem than the current one, and those $47 \%$ of men / women who did so in 2011 for the first time and answered when presented with the questionnaire at the location where they were during the treatment (Figure 3).
Observou-se uma distribuição homogénea destes utentes relativamente à adesão em função do sexo por dois grupos: os que já fizeram acupunctura anteriormente para tratar o mesmo ou outro tipo de problema que não o atual, $53 \%$ de homens/mulheres, e os que o fizeram em 2011 pela $1^{\mathrm{a}}$ vez no tratamento em que se encontravam por ocasião da resposta ao questionário, $47 \%$ dos homens/mulheres (Figura 3 ).

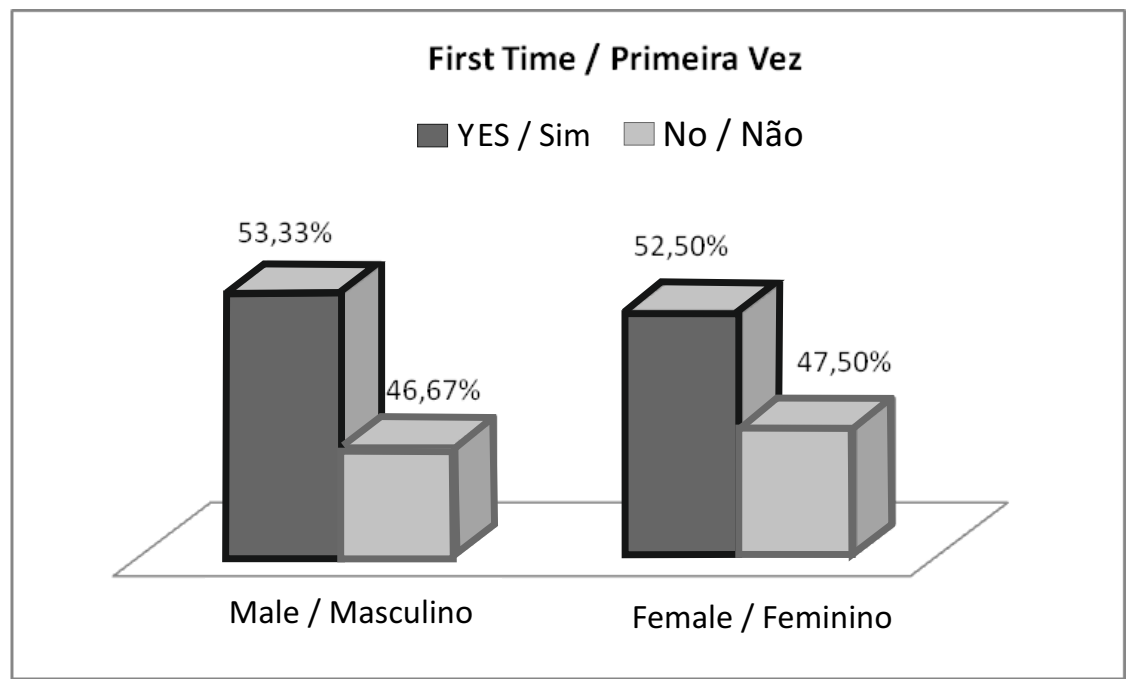

Figure 3 - Population referring to participants who were submitted to acupuncture

Figura 3 - População que recorre ou não à acupunctura pela primeira vez.the first time or not. 
Approximately $40 \%$ of the population claims to have opted for this treatment on the recommendation of a friend to try this type of therapy; $32 \%$ turned to it on their own initiative, $22 \%$ following advice from a health care professional and only $6 \%$ answered none of the above, saying they had been advised by a relative (Figure 4). As for the choice of therapy, the majority of the population did so by choice $(64 \%)$ and not out of obligation or monetary issues $(<1 \%)$, while $31 \%$ indicated that the choice of therapy has resulted from the absence of a therapeutic result by said conventional medicine.

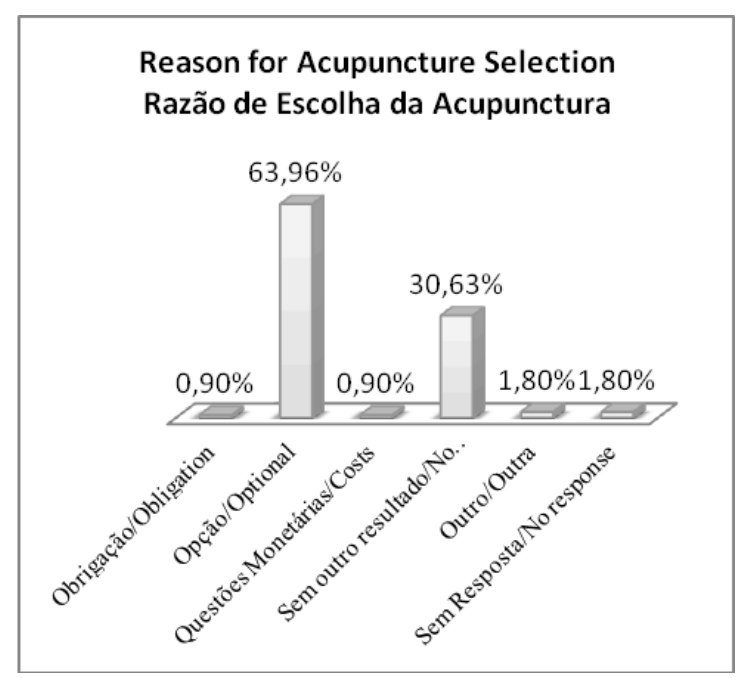

When asked about how they classified the site where they were, whether hospital, medical clinic, health center or center for traditional Chinese medicine, 70\% (78/111) of the people involved did not answer the question. Of those who did, $36 \%$ were attending centers for traditional Chinese medicine and $61 \%$ were attending western medical clinics (Figure 5), which highlights the significance of traditional referenced centers.
Cerca de $40,00 \%$ da população estudada afirma ter sido realizado este tratamento por recomendação de um amigo para recorrer a este tipo de terapia; 32\% recorreu por iniciativa própria, $22 \%$ por aconselhamento de um profissional de saúde e apenas $6 \%$ não respondeu a nenhuma das opções anteriores dizendo ter sido aconselhada por um familiar (Figura 4). Quanto à escolha da terapia, a maioria da população fê-lo por opção (64\%) e não por obrigação ou por questões monetárias $(<1 \%)$, embora $31 \%$ tenham indicado que a escolha da terapia resultou da ausência de resultado pela medicina dita convencional.

Figure 4 - Main reason given by patients for choosing acupuncture.

Figura 4 - Principal razão apontada pelos doentes para escolha de acupunctura.
Inquiridos sobre como enquadravam o local onde se encontravam, se hospital, clínica médica, centro de saúde ou casa de medicina tradicional chinesa, 70\% (78/111) das pessoas intervenientes não responderam à questão, verificando-se entre os respondentes que 36\% frequentavam Casas de Medicina Tradicional Chinesa e $62 \%$ frequentavam Clínicas Médicas (Figura 5), o que evidencia a importância dos centros referenciados como tradicionais.

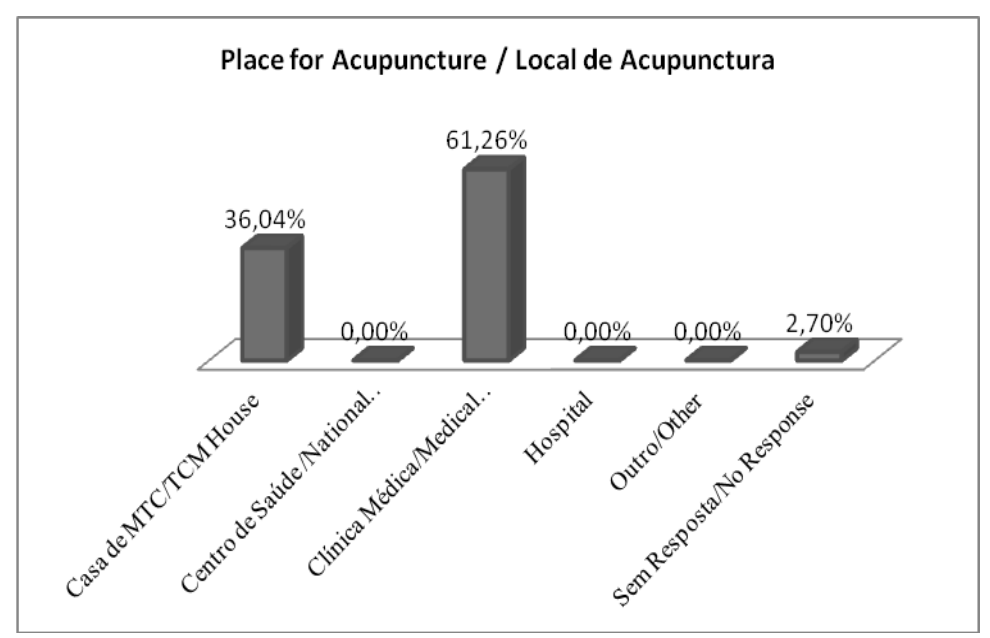

Figure 5 - Local acupuncture frequented by study population $(\mathrm{N}=111)$.

Figura 5 - Local de acupunctura frequentado pela população em estudo $(\mathrm{N}=111)$. 
Of the respondents, only $5 \%$ answered not knowing if their acupuncturist is a doctor belonging to the Medical Council or to Traditional Chinese Medicine (Figure 6). More than half (54\%) answered that their practitioner is a "doctor of traditional Chinese medicine".

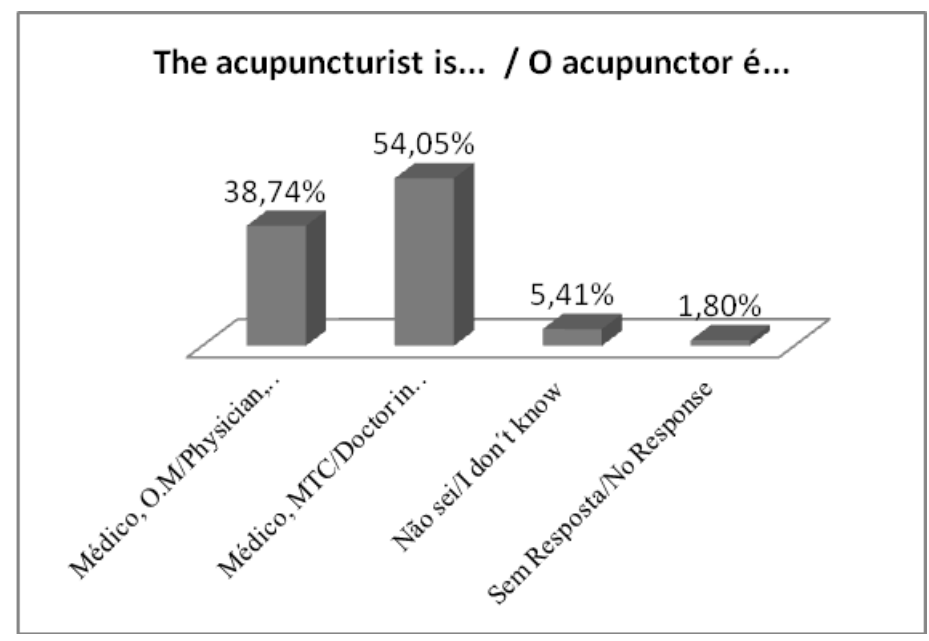

Dos inquiridos, apenas $5 \%$ respondeu não saber se o seu acupunctor é médico pertencente à Ordem dos Médicos ou de Medicina Tradicional Chinesa (Figura 6), informando mais de metade (54\%) ser um "médico de medicina tradicional chinesa".

Figure 6 - Answer to the question: "Your acupuncturist is ...?" Figura 6. - Resposta à questão: "O seu acupunctor é ...?"
Of the population studied, $98 \%$ indicated they were satisfied with the competence demonstrated by the acupuncturist during therapy (Figure 7).

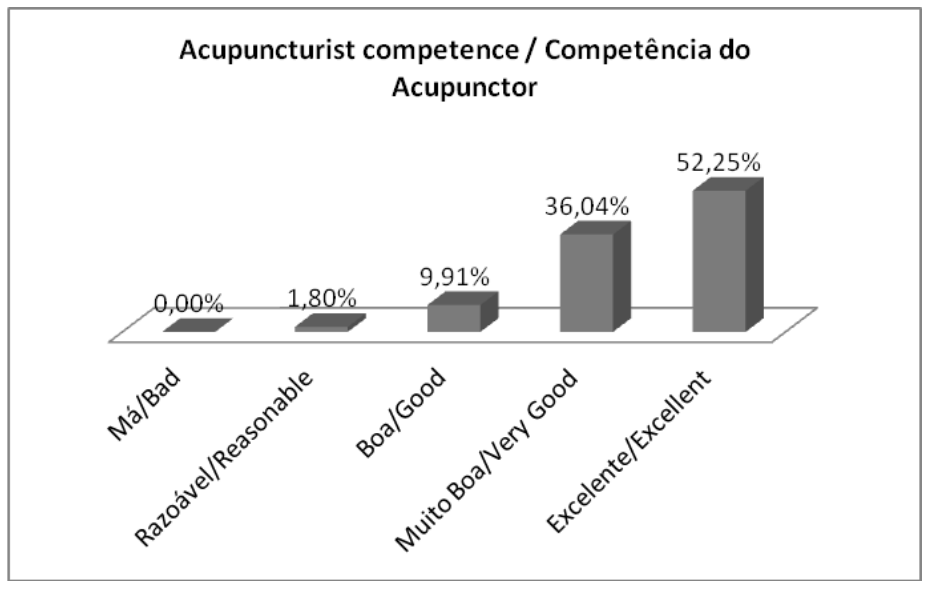

Da população estudada, $98 \%$ mostra-se satisfeita com a competência demonstrada pelo acupunctor no decorrer da terapia (Figura 7).

Figure 7 - Review of competence demonstrated by your acupuncturist.

Figura 7 - Opinião sobre competência demonstrada pelo seu acupunctor.
Less than $2 \%$ of people said they had unsatisfactory results, a percentage equal to those who did not reply, and less than $1 \%$ expressed dissatisfaction with the results in relation to their problem (Figure 8).
Menos de 2\% das pessoas disseram ter resultados pouco satisfatórios, uma percentagem igual à dos que não responderam à questão, e menos de $1 \%$ manifestou não estar satisfeita com os resultados perante o seu problema (Figura 8). 


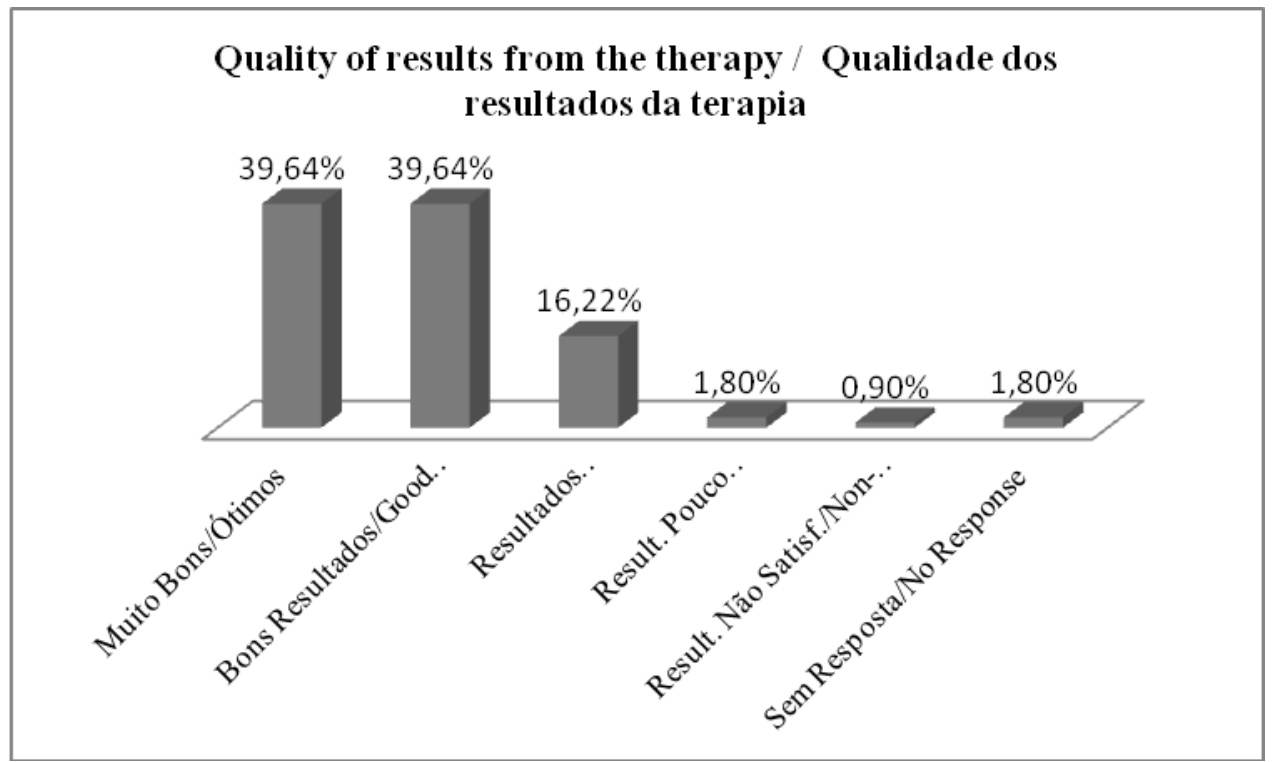

Figure 8 - Opinion on the results of acupuncture for your problem.

Figura 8 - Opinião sobre os resultados da acupunctura para o seu problema.

A number of $94 / 111$ (85\%) of the population reported that before starting acupuncture they had already tried to get treatment for their problem through conventional medicine but the results had not been satisfactory. Table 1 summarizes the five most common problems reported in the study population for which they found justification to recourse to this type of treatment.
Antes de iniciar a acupunctura, $85 \%$ da população refere ter já tentado obter tratamento para o seu problema através da medicina convencional, onde não terá encontrado resultados satisfatórios. A Tabela 1 resume os 5 problemas comuns relatados como principais para os quais a população recorre a este tipo de tratamento.

\section{Problem / Problema}

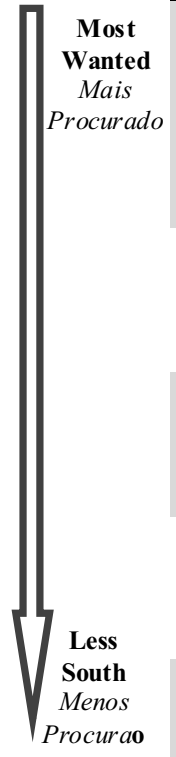

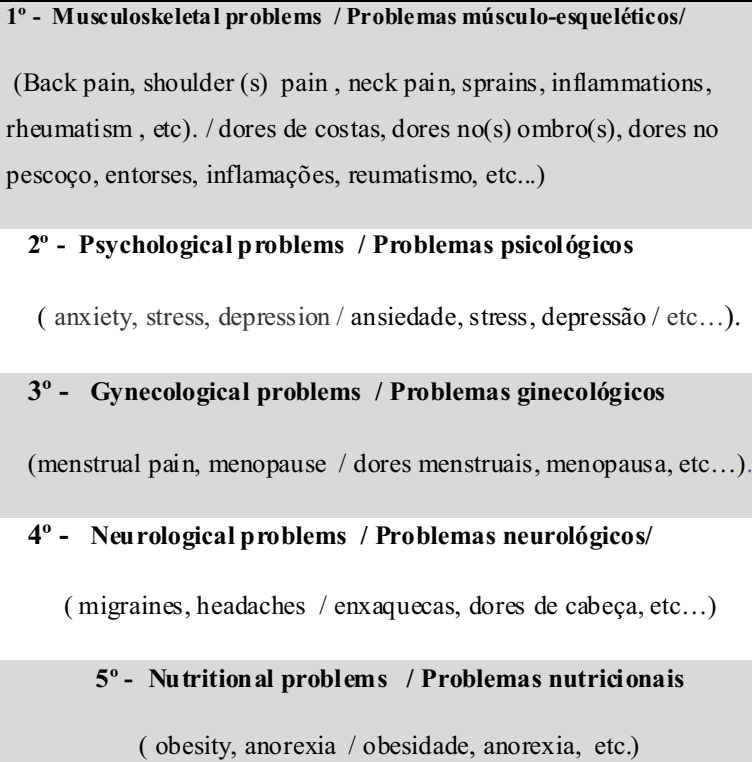

Table 1 - Major problems reported that led people to resort to acupuncture.

Tabela 1 - Principais problemas relatados que levaram a recorrer à acupunctura. 
More than half of the population reported having a chronic problem or complaint about the same disorder for over a year (Figure 9).
Mais de metade da população referiu ter um problema crónico ou queixar-se do mesmo há mais de um ano (Figura 9).

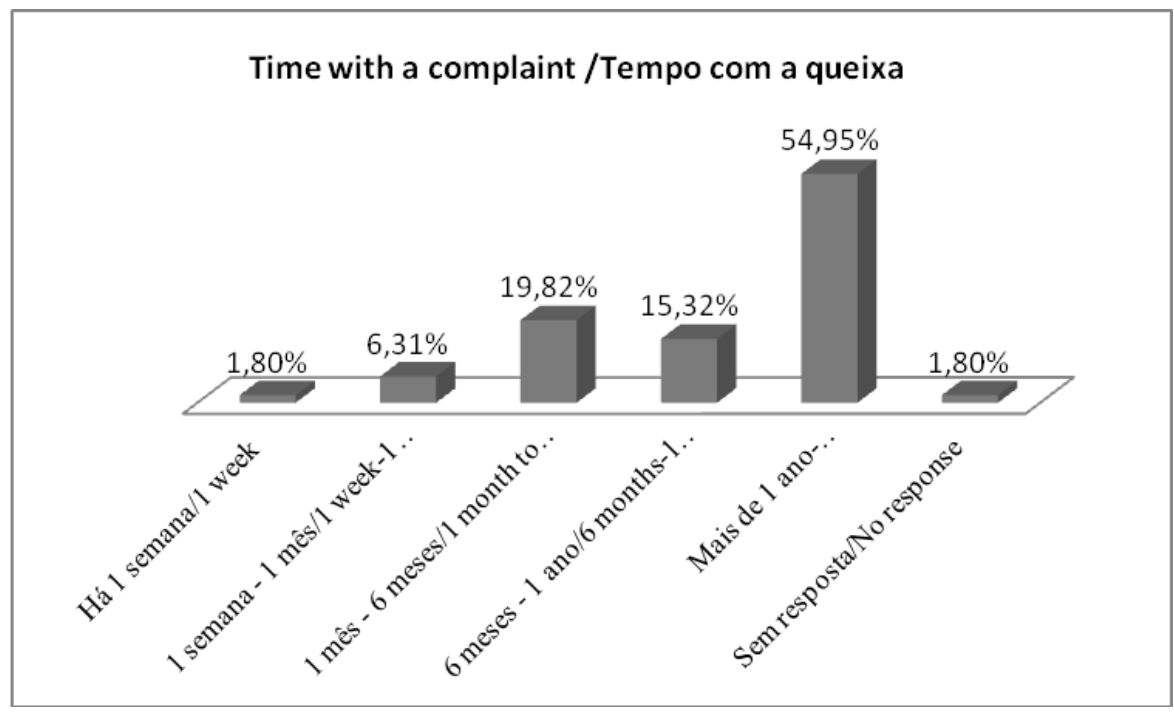

Figure 9 - How long did you have to complain to your problem?

Figura 9 - Há quanto tempo tem a queixa para o seu problema?

Finally, patients were shown to be mostly pleased with the therapy, indicating how good (32\%) and very good $(22 \%)$ the price-quality ratio of the therapy is. For a total of $6 \%$ of patients, the therapy was not very satisfactory or unsatisfactory.

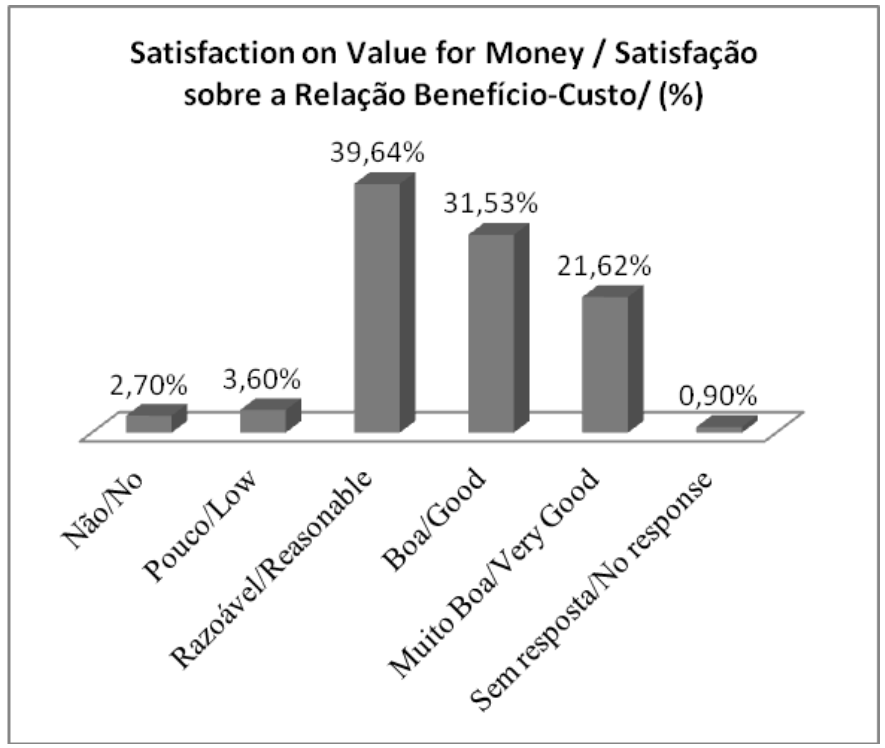

Por fim, os doentes mostraram-se maioritariamente agradados, indicando como boa $(32 \%)$ e muito boa $(22 \%)$ a relação benefício-custo da terapia, sendo pouco satisfatória ou não satisfatória para um total de $6 \%$ dos doentes.

Figure 10 - Opinion of respondents regarding the value for money of therapy.

Figura 10 - Opinião dos inquiridos quanto à relação benefício-custo da terapia. 


\section{Discussion of Results}

In the study sample, it was found that there is a greater demand among women, nearly three times higher than for men $(73: 27)$. For both sexes, those who more commonly search for this therapy are between 31 and 50 years, followed by the age group 51 to 65 years. Given that the costs of acupuncture are not subject to any reimbursement by the National Health Service, or the majority of private health insurance, in the opinion of the users the value for money of the treatment provided is deemed reasonable for the majority $(40 \%)$, good $(32 \%)$ or very good $(22 \%)$. This result is important considering the fact that these age groups (31-65 years) are more economically autonomous enabling them to take advantage of such services, in comparison with younger people.

Friends are the main source of recommendation in the study population (40\%) who choose acupuncture, but $32 \%$ of users claim to have sought acupuncture of their own accord and only $22 \%$ followed guidelines from a professional. Still, the vast majority $(85 \%)$ has only resorted to acupuncture after experiencing treatment by conventional medicine where more than half $(67 \%)$ were dissatisfied with the results of this conventional treatment. Comparing this study to the one by DECO in $2001^{(5)}$, the results are not very different for the date, $88 \%$ of respondents said they had sought conventional treatment before choosing this therapy.

More than half (ca. 52-53\%) of the population are not undergoing this type of treatment for the first time, having already sought acupuncture for other condition(s). This is the case for both female and male clients.

Most people say that their acupuncturist is a Dr. of Traditional Chinese Medicine, but it should be noted that many of the respondents are attending a medical clinic. Therefore we conclude that there are still some people who do not know exactly what type of health care practitioner they are dealing with. However, this seems not to be of concern since the majority of respondents are satisfied with the competence shown and performed by the practitioner, who are highly rated as excellent and/or very good (88\%), again similar to the answers in the study by $\mathrm{DECO}^{(5)}$.

As for the health problems that led these respondents to the acupuncturist, the problems are musculoskeletal, psychological, gynecological, neurological and nutritional, representative of the problems in our country. There is considerable demand for such localized pain therapy. However, when interpreting the collected results, it can be seen that these respondents make use of acupuncture for simultaneous relief of other complaints such as anxiety disorders, because for some, the treatment is assigned to more than one pathology.

\section{Discussão de Resultados}

$\mathrm{Na}$ amostra em estudo, verificou-se existir uma maior procura por parte das mulheres perto de três vezes superior à dos homens $(73: 27)$. Para ambos os sexos, quem mais procura esta terapia tem entre 31 e 50 anos, seguindo-se a faixa etária dos 51 aos 65 anos. Atendendo a que as despesas com a acupunctura não são alvo de qualquer reembolso por parte do Serviço Nacional de Saúde, nem da maioria dos seguros de saúde privados, na opinião dos utentes a relação benefício-custo do tratamento prestado é considerada maioritariamente razoável $(40 \%)$, boa $(32 \%)$ ou muito boa $(22 \%)$.

Este resultado tem relevância se atendermos ao facto de estas faixas etárias (31 a 65 anos) serem economicamente mais autónomas para poderem usufruir deste tipo de serviços, que as mais jovens.

São os amigos a principal fonte de recomendação da população em estudo (40\%) para escolher a acupunctura; porém, $31,53 \%$ dos utentes afirmam ter tido iniciativa própria de a procurar e apenas $22 \%$ seguiu orientações de um profissional. Ainda assim, a grande maioria $(85 \%)$ só terá recorrido à acupunctura depois de ter experimentado um tratamento pela medicina convencional mostrando-se, mais de metade $(67 \%)$ insatisfeita com os resultados do anterior. Comparativamente ao estudo efetuado pela DECO, em $2001,{ }^{(5)}$ os resultados não são muito divergentes pois à data, $88 \%$ dos inquiridos afirmaram ter procurado um tratamento convencional antes de escolher esta terapia. Mais de metade (ca. 52-53\%) da população estudada não realiza pela primeira vez este tipo de tratamento, pelo que já o terá procurado a acupunctura para outra(s) patologia(s) o que se verifica tanto para o sexo feminino como masculino.

A maioria responde que o seu Dr. acupunctor é de Medicina Tradicional Chinesa mas, observando que grande parte diz frequentar uma clínica médica, conclui-se que ainda há algumas pessoas que não sabem exatamente com que tipo de profissional estão a lidar. Contudo, tal parece não ser uma preocupação já que se mostram satisfeitas com a competência desempenhada pelo mesmo, que é expressivamente qualificada (88\%) como excelente e muito boa, à imagem do que foi respondido também, no estudo da $\mathrm{DECO}^{(5)}$.

Quanto aos problemas de saúde que levaram estes inquiridos ao acupunctor, são os problemas músculoesqueléticos, psicológicos, ginecológicos, neurológicos e nutricionais mais representativos no nosso país. É considerável a procura desta terapia para dores localizadas mas, ainda assim, perante os resultados obtidos, não se pode constatar que estes recorram menos à mesma que inquiridos com problemas de ansiedade, por hipótese, já que a maioria 
Ten years after a similar study performed by DECO ${ }^{(5)}$ the musculoskeletal problems (e.g. back pain, pain in the shoulder (s), neck pain, sprains, inflammations, rheumatism) remain the most common to be treated by this therapy. These are followed by the psychological problems, for example, depression, anxiety and stress. New trends in the motivations for seeking acupuncture treatment in the study population, including gynecological problems such as menstrual pain and menopause, have increased considerably over the years, taking into account that these were one type of the problems with less percentage of adherence in the former study. Finally, acupuncture was voted fifth place in the treatments addressing nutritional problems, such as obesity and anorexia, and demand for it has increased four times more than twelve years ago.The results obtained by participants in the study, indicate that in relation to the treatment of the problem (s) indicated, the majority (93\%) claim to have obtained very good, good and reasonable results, showing their satisfaction thereof. The participants involved in the study by DECO in $2001{ }^{(5)}$ were also satisfied with their treatment in comparable percentages, which suggests that the Portuguese population has a stable good degree of adherence to this therapy, perceiving that acupuncture provides relief of their symptoms.

\section{Conclusions}

Middle-aged women show the most active use of acupuncture. Although no negative reactions relevant to the benefit-cost ratio were exhibited by the users, the fact that the majority of acupuncture patients reveal satisfaction with quality of care minimizes the importance of cost parameters that would have to be the subject of a properly designed and deeper study.

This exploratory study in the Lisbon region demonstrates similar findings to what was observed in 2001 by the Portuguese Consumer Defense Directorate (DECO). Acupuncture is shown to be taken into account as a second treatment option to which the population turns mostly when conventional medicine does not bring results. Although the results of this therapy are considered variable by specialists because they can be either delayed or provide immediate relief of pain in certain acute situations, users from older age groups and those with complaints for more than one year or with chronic diseases say they obtain satisfactory results.

For the last ten years, both the musculoskeletal and the psychological problems have been the most evident reason for the Portuguese population to seek therapy faz tratamentos para mais do que uma patologia.

Dez anos após o estudo semelhante efetuado pela DECO ${ }^{(5)}$, os problemas músculo-esqueléticos (por exemplo, dores de costas, dores no (s) ombro(s), dores no pescoço, entorses, inflamações, reumatismo, continuam a ser os mais procurados para serem tratados por esta terapia, seguindo-se os do foro psicológico, por exemplo, depressão, ansiedade, stress. Em termos de novas tendências regista-se a procura da acupunctura, pela população estudada para problemas ginecológicos, tais como dores menstruais e menopausa, aumentou consideravelmente ao longo dos anos, tendo em conta que estes eram um dos problemas com menos percentagem de adesão terapêutica, no antigo estudo. Por fim, a acupunctura foi eleita em $5^{\circ}$ lugar para tratar problemas nutricionais, por exemplo, obesidade e anorexia, tendo aumentado a sua procura para tal quatro vezes mais que há doze anos.

Dos resultados obtidos pelos intervenientes no estudo, em relação ao tratamento para o(s) seu(s) problema(s), a maioria diz ter obtido ótimos, muito bons e bons resultados, em igual percentagem, pelo que se mostram satisfeitos com os mesmos. Também os intervenientes no estudo da DECO em $2001^{(5)}$ se mostraram satisfeitos com o seu tratamento, o que sugere que a população portuguesa que conhece a acupunctura tem um bom grau de adesão a esta terapia para alívio dos seus sintomas.

\section{Conclusões}

São mulheres de meia-idade que mais recorrem à acupunctura. Embora não se manifestem reações negativas relevantes em relação à razão benefíciocusto por parte dos utentes, o facto de as estatísticas revelarem satisfação maioritária com a qualidade no tratamento, pode evidenciar uma minimização da importância dos custos, parâmetros que teriam de ser objeto de um estudo mais profundo.

Neste estudo exploratório na região de Lisboa, e à semelhança do que foi constatado pela DECO em 2001, a acupunctura é tida em conta como uma segunda opção terapêutica, à qual a população recorre maioritariamente quando não obtem resultados na medicina convencional. Apesar de os resultados desta terapia serem considerados variáveis pelos especialistas, pois tanto podem ser retardados como ocasionar um alívio imediato da dor, em certas situações agudas, os utentes de faixas etárias mais elevadas e com queixas superiores a um ano ou com doenças crónicas, dizem conseguir obter resultados satisfatórios.

Os problemas músculo-esqueléticos e psicológicos estão, há 12 anos, a razão mais evidenciada para a 
through acupuncture.

In November 2012 the Portuguese government approved a draft law on non-conventional therapies, which states that they can only be practiced by those who have higher education and are professionally licensed on the public register. The draft regulation approved by the Council of Ministers establishes the access and exercise of professionals who practice acupuncture, homeopathy, osteopathy, naturopathy, herbal medicine and chiropractic. Based on the World Health Organization guidelines, the regulation establishes the functional profiles of each of the six non-conventional therapies, determining that they can only be practiced by those who have higher-education training, defined by ordinance. The practice of these therapies will also imply the assignment of a professional certificate with public register, which will allow citizens to identify professionals with appropriate training.

\section{Conflict of Interests}

The authors declare that there is no financial or personal relationship that can be understood as representing any potential conflict of interest. população portuguesa procurar a terapia através de acupunctura.

O Governo português aprovou em novembro de 2012 uma proposta de lei sobre terapêuticas não convencionais, que dispõe que só podem ser praticadas por quem tenha formação superior e cédula profissional com registo público.

O diploma aprovado em Conselho de Ministros estabelece o regime de acesso e exercício dos profissionais que praticam acupunctura, homeopatia, osteopatia, naturopatia, fitoterapia e quiropraxia.

Partindo das orientações da Organização Mundial da Saúde, são estabelecidos os perfis funcionais de cada uma das seis terapêuticas não convencionais, determinando-se que as mesmas só podem ser praticadas por quem tenha uma formação, de nível superior, a definir por portaria.

A prática destas terapêuticas vai implicar ainda a atribuição de uma cédula profissional com registo público, o que permitirá aos cidadãos identificar quais os profissionais com formação adequada.

\section{Conflitos de interesse}

Os autores declaram não existir qualquer relação de natureza financeira ou pessoal que possa ser entendida ou representar um potencial conflito de interesses.

\section{References / Referências}

[1]. The Center for Integrative Medicine at Duke University, EUA, 2006, A Enciclopédia da Nova Medicina, Rio de Mouro, Ed. Círculo de Leitores, pág. $446 \& 464$

[2]. Wu, Cecilia; Weber, Wendy; Kozak, Leila; Standish, Leanna J.; Ojemann, Jeff G.; Ellenbogen, Richard G. and Avellino, Anthony M., 2009, A Survey of Complementary and Alternative Medicine (CAM) - Awareness Among Neurosurgeons in Washington State, Washington, 15 (5), pp. 551-555;
[3]. Almeida Joana, The differential incorporation of CAM into the medical establishment: The case of acupuncture and homeopathy in Portugal, Health Sociology Review, (2012) Vol. 21 Issue 1, p5-22. 18p. [4]. Robinson N, Lorenc A, Ding W, Jiac J, Bovey M, Wang X. Exploring practice characteristics and research priorities of practitioners of traditional acupuncture in China and the EU-A survey, Journa of Ethnopharmacology, Volume 140, Issue 3, 10 April 2012, Pages 604-613
[5]. DECO - Associação Portuguesa para a Defesa do Consumidor, 2001, "Acupunctura: que resultados?", in Teste Saúde, Lisboa, DECOPROTESTE Editores, Lda, Mar/Abr, (30), pp. 14-19. 